\title{
The Effect of Geometrical Parameters on Heat Transfer Characteristics of Compact Heat Exchanger with Louvered Fins
}

\author{
P. Gunnasegaran, ${ }^{1}$ N. H. Shuaib, ${ }^{2}$ and M. F. Abdul Jalal ${ }^{1}$ \\ ${ }^{1}$ Centre for Advanced Computational Engineering (CACE), College of Engineering, Universiti Tenaga Nasional, \\ Putrajaya Campus, Jalan IKRAM-UNITEN, 43000 Kajang, Malaysia \\ ${ }^{2}$ TNB Research Sdn. Bhd., Tenaga Nasional Berhad, Jalan Ayer-Hitam, 43000 Kajang, Malaysia
}

Correspondence should be addressed to P. Gunnasegaran, prem@uniten.edu.my

Received 3 September 2012; Accepted 1 October 2012

Academic Editors: G. L. Aranovich, S. Hashimoto, and H. Hirao

Copyright ( $) 2012$ P. Gunnasegaran et al. This is an open access article distributed under the Creative Commons Attribution License, which permits unrestricted use, distribution, and reproduction in any medium, provided the original work is properly cited.

Compact heat exchangers (CHEs) have been widely used in various applications in thermal fluid systems including automotive thermal management systems. Among the different types of heat exchangers for engine cooling applications, cross-flow CHEs with louvered fins are of special interest because of their higher heat rejection capability with the lower flow resistance. In this study, the effects of geometrical parameters such as louver angle and fin pitch on air flow and heat transfer characteristics on $\mathrm{CHEs}$ are numerically investigated. Numerical investigations using five different cases with increased and decreased louver angles $\left(+2^{\circ},+4^{\circ}\right.$, $-2^{\circ},-4^{\circ}$, and uniform angle $\left.20^{\circ}\right)$, with a fixed fin pitch and using three different fin pitches $(1.0 \mathrm{~mm}, 2.0 \mathrm{~mm}$, and $4.0 \mathrm{~mm})$, and with the fixed louver angle are examined. The three-dimensional (3D) governing equations for the fluid flow and heat transfer are solved using a standard finite-volume method (FVM) for the range of Reynolds number between 100 and 1000. The computational model is used to study the variations of pressure drop, flow temperature, and Nusselt number.

\section{Introduction}

In recent years, due to the increasing demand by industries for heat exchangers that are more efficient, compact, and less expensive, heat transfer enhancement has gained great momentum. Thus, engineers come out with one brilliant solution to deal with this issue, at which one innovation device has been developed decades ago called compact heat exchanger (CHE). CHEs are characterized by a high surface area per unit volume, which can result in a higher efficiency than conventional heat exchangers. Hence, CHEs are able to transfer more energy in a cost-effective manner than other types of heat exchangers and enable more energy saving when compared to standard technology [1-3]. CHEs have been widely used in automotive thermal fluid systems such as radiators or air coolers for engine cooling systems and as intercoolers in turbocharging systems. In general, designing of CHEs is required to increase energy saving. The way to improve the thermal performance of CHEs is to find efficient heat transfer surfaces that do not induce much pressure loss. For this purpose, two techniques have been identified which are "passive" and "active" [4]. Passive technique uses special geometries or fluid additives. Active technique has attracted relatively little attention in research and practice due to more costs involved. The passive technique through the use of various surface geometries such as louvered fins CHE is preferred [5].

Webb [6] provides a survey of the published data and correlations. Louver fin geometry is used widely for heat transfer to air in automotive and room air conditioning heat exchangers such as radiators, condensers, and oil coolers. The louvers act to interrupt the airflow and create a series of thin boundary layers that have lower thermal resistance. Experimental studies aimed at optimizing louvered fin geometries tend to be costly and time-consuming because of the large number of geometrical parameters involved such as louver 
angle, louver pitch, louver length, and fin pitch. Thus, Webb and Trauger [7] and Sahnoun and Webb [8] in their further research used visualization techniques to investigate the relationship between the flow alignment and the geometrical parameters of the louver angle, louver pitch, and fin pitch. They found that the degree of flow alignment at a given Reynolds number is increased as the fin-to-louver pitch ratio is reduced.

Kim and Bullard [9] studied experimentally the air-side thermal and hydraulic performance of multi-louvered fin aluminum heat exchangers. According to them, a multilouvered fin and flat tube CHE is one of the other alternatives that can replace conventional finned-tube heat exchangers. The air-side thermal and hydraulic performance of multilouvered fin and flat tube CHE depends on louver geometry such as fin and louver pitches, louver angle, and flow depth. They concluded that the heat transfer coefficient increases exponentially with face air velocity and decreases with flow depth. Also, pressure drop increases with the increase of louver angle and flow depth and decreases with the increase of fin pitch.

Phan et al. [11] experimentally investigated the effect of a tube row, a fin pitch, and the inlet humidity on airside heat and mass transfer performance of louvered fintube heat exchangers under wet condition. The condition is varied by three fin pitches, two different numbers of tube rows, and two inlet relative humidities. The arrangement of the apparatus consists of a humidity chamber, a cord tester, a water bath, an air-sampling unit, and a data acquisition system. The type of fin used in their study is louver with three different fin pitches $(1.42 \mathrm{~mm}, 1.62 \mathrm{~mm}$, and $1.83 \mathrm{~mm})$ and two different numbers of tube rows which are 2 and 3. From their results, it has been noted that for two rows of tube heat exchanger, the heat transfer decreases and the friction increases with the increasing of fin pitch. The $j$-factor and $f$ factor of the fin pitch $1.83 \mathrm{~mm}$ are lower about $16.4 \%$ and are higher about $22.3 \%$, respectively, than those of the fin pitch $1.42 \mathrm{~mm}$. The flow pattern at wet condition of the fin-tube exchanger is different from that at dry condition. When the fin pitch is small, the quantity of condensate water remaining on the fin-tube surface increases and distorts the air flow pattern across the heat exchanger more intensely which leads to higher heat transfer.

The effect of geometrical and environmental parameters on thermal and hydraulic performance of louver fin flat plate CHE are experimentally studied by Zhong and Jacobi [12]. For the apparatus, it consists of an environmental chamber, a wind tunnel with heat exchanger test section, a coolant supply system, and also a data acquisition system that was constructed to test the CHE under frosting condition. They pointed out in their experimental work that the increasing in frost accumulation is a strong function of the operating condition. It seems that the ratio of the pressure drop during frost growth to the initial pressure drop without frost is same for that CHE with same flow depth but different in fin pitches. A low coolant temperature, large air flow depth, or small fin pitch lead to a fast increase in pressure drop.

Cowell et al. [13] and Achaichia and Cowell [14] studied the heat transfer performance of multi-louvered fin in CHE.
They pointed out that the louvered fin CHE provides better heat transfer performance than other types of heat exchanger due to the louver array's flow directing properties which caused the increment in velocity of the working fluid relative to the elemental flat-plate surfaces. Other important factors are because of the manufacturing advantages of louvered fins, which can be produced with larger fin height and higher fin density. The larger fin height and greater fin density yield surfaces with a larger proportion of enhanced secondary surface. From their studies, it can be seen that louvered fins have higher values of the hydraulic diameter ratio than any of the surfaces, and it can be concluded that these louvered fins are worthy of consideration for applications in which size, weight, and pumping power are particularly important.

Malapure et al. [15] performed numerical investigations on the fluid flow and heat transfer characteristics over louvered fins and flat tube in CHEs. Each case is performed for different geometries with change of louver pitch, louver angle, fin pitch, and tube pitch and also for different Reynolds number cases. They found that at low Reynolds number, the flow is fin-directed; while at high Reynolds number, the flow is louver-directed. They concluded that the Nusselt number is substantially high at the fin tip and at the leading and trailing edges of the louver. The friction factor decreases with the increase of fin pitch.

Jung and Assanis [16] outlined in their numerical work that a predictive heat exchanger model is advised for the investigation of the effect of the geometric changes due to the nonlinear characteristics of the heat exchanger performance related to geometric changes. For the demonstration of the predictive capability of the model, the effects of the radiator aspect ratio and the core size on the heat rejection rate were explored and presented in their study. Their results show that radiator with larger aspect ratio performed better than smaller aspect ratio case. Heat rejection was increased as much as $8 \%$ by changing the aspect ratio from 0.5 to 1.5 with the same core size. They also found that as the core size is reduced, the heat rejection rate is decreased, but not in a proportional manner. A more comprehensive study was carried out by Kajino and Hiramatsu [17]. They solved the stream function and vorticity equations for incompressible, steady, and laminar two-dimensional flows over flat louvered fins using finite difference methods.

Although many studies on louver fin have been reported; they are based on the assumption that the louver angle is uniform. Hsieh and Jang [10] numerically computed the conjugate heat transfer characteristics of the louver fin heat exchangers with variable louver angle. Their results indicated that the successively variable louver angle patterns applied in heat exchangers could effectively enhance the heat transfer performance. Their invention initiated the present study to gain further insight into the louvered fin CHE. Thus, the present study deals with 3D numerical simulations of laminar flow and heat transfer characteristics of variable louver angles and fin pitches in CHE using Reynolds number ranging from 100 to 1000 . Results of interests such as Nusselt number and pressure drop coefficient are reported to illustrate the effects of change in louver angle and fin pitch on CHE performance. 


\section{Formulation of the Problem}

2.1. Model Description. This study covered the investigation, simulation, and the analysis of changes in geometrical parameters changes of louvered fin compact heat exchanger, CHE. Figure 1 shows the physical model and computational domain for the louvered fin CHE. The model consists of an entrance and exit louver with three louver fins on either side of the centre of the fin geometry. For basic information, louver pattern is generally a pattern like window with horizontal slats at which each one of the rectangular plate from Figure 1 is designed with some inclination angles. This louver pattern is applied along the fin of the CHE. In every layer of the fin, the pattern is designed as in Figure 2 to improve the performance of heat rejection as the fin design plays the biggest role in producing the highest efficiency of the CHE. Also, the flow for each case will be assumed as laminar flow for inlet air velocity ranged from $0.3 \mathrm{~m} / \mathrm{s}$ to $15 \mathrm{~m} / \mathrm{s}$. As for this investigation, the performance of louvered fin CHE on thermal and hydraulic analysis is evaluated by varying the louver angle and fin pitch.

2.2. The Effect of Louver Angle. In this section, the analysis is carried out by using five different cases in different arrangement of louver angles as shown in Figure 2. By referring to Figure 2, five different cases of successively increased and decreased louver angle $\left(+2^{\circ},+4^{\circ},-2^{\circ},-4^{\circ}\right.$, and uniform angle $20^{\circ}$ ) are investigated in this study as listed below:

(1) case A $\left(20^{\circ}, 22^{\circ}, 24^{\circ}, 26^{\circ}, 24^{\circ}, 22^{\circ}, 20^{\circ}\right)$;

(2) case $\mathrm{B}\left(20^{\circ}, 24^{\circ}, 28^{\circ}, 32^{\circ}, 28^{\circ}, 24^{\circ}, 20^{\circ}\right)$;

(3) case $\mathrm{C}\left(26^{\circ}, 24^{\circ}, 22^{\circ}, 20^{\circ}, 22^{\circ}, 24^{\circ}, 26^{\circ}\right)$;

(4) case $\mathrm{D}\left(32^{\circ}, 28^{\circ}, 24^{\circ}, 20^{\circ}, 24^{\circ}, 28^{\circ}, 32^{\circ}\right)$;

(5) case $\mathrm{E}\left(20^{\circ}, 20^{\circ}, 20^{\circ}, 20^{\circ}, 20^{\circ}, 20^{\circ}, 20^{\circ}\right)$, uniform angle of $20^{\circ}$.

According to the 5 listed cases, for case $\mathrm{A}$, the louver angle is added by $2^{\circ}$, towards the center of the fin surfaces, and for case B, the louver angle is added by $4^{\circ}$, towards the center of the fin surfaces, and both cases showed that the louver tilt angles of the inlet fins are set to be $20^{\circ}$, and the three entrance louvered fins and frontal redirection are successively increased by $2^{\circ}$ and $4^{\circ}$, respectively, and then another three are successively decreased $2^{\circ}$ and $4^{\circ}$, towards the exit. Apart from that, for case $\mathrm{C}$, the louver angle is decreased by $2^{\circ}$, towards the center of the fin surfaces, and for case $\mathrm{D}$, the louver angle is decreased by $4^{\circ}$, towards the center of the fin surfaces, and both these cases showed that the louver tilt angles of the inlet fins are set to be $26^{\circ}$ for case $\mathrm{C}$ and $32^{\circ}$ for case $\mathrm{D}$, and the three entrance louvered fins and frontal redirection are successively decreased by $2^{\circ}$ and $4^{\circ}$, respectively, and then another three are successively increased $2^{\circ}$ and $4^{\circ}$, towards the exit. Also, case E is set up to have uniform $20^{\circ}$ for the entire louver angle taken from the inlet up to the outlet. The specified dimensions of the present louvered fin $\mathrm{CHE}$ for this analysis are given as follows.

Fin pitch $(1.00 \mathrm{~mm})$;

Louver pitch $(1.00 \mathrm{~mm})$;

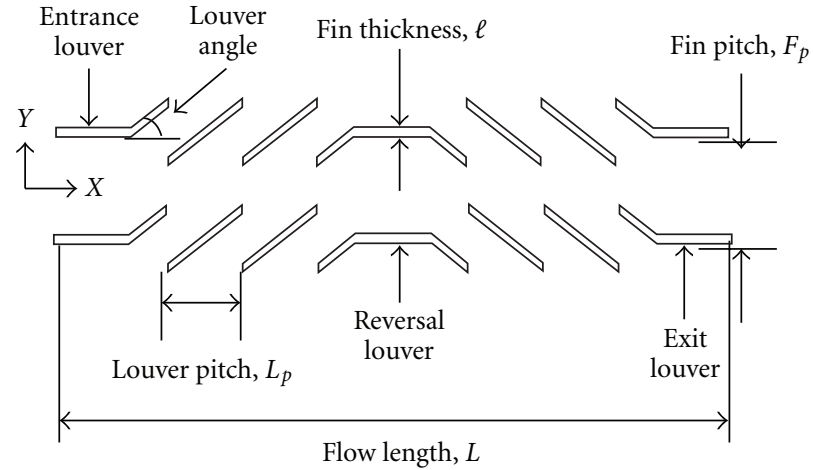

(a)

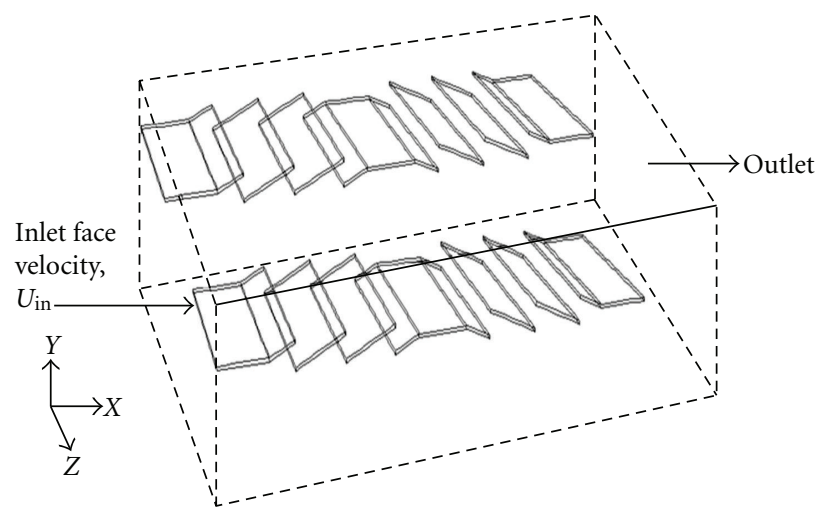

(b)

Figure 1: (a) The physical model (2D view in $X-Y$ plane) and (b) computational domain.
Fin thickness $(0.05 \mathrm{~mm})$;
Flow length $(9.00 \mathrm{~mm})$;
Inlet air temperature $\left(T_{\text {in }}\right)\left(20^{\circ} \mathrm{C}\right)$;
Inlet air pressure $\left(P_{\text {in }}\right)(0.0 \mathrm{~Pa})$;
Fin wall temperature $\left(T_{w}\right)\left(60^{\circ} \mathrm{C}\right)$;
Frontal velocity $\left(u_{\text {in }}\right)(1 \sim 15 \mathrm{~m} / \mathrm{s})$.

2.3. The Effect of Fin Pitch. To investigate the effect of fin pitch on heat transfer performance of louvered fin CHE, the louver angle chosen is fixed at $20^{\circ}$ throughout along the fin but the fin pitch is now chosen to be the variable. It consists of three variables which are

(1) case A (fin pitch $=1.0 \mathrm{~mm}$ );

(2) case $B$ (fin pitch $=2.0 \mathrm{~mm}$ );

(3) case C (fin pitch $=4.0 \mathrm{~mm}$ ).

For each case, the other dimensions of the CHE are being fixed as stated below.

Louver pitch $(1.00 \mathrm{~mm})$;

Fin thickness $(0.05 \mathrm{~mm})$;

Flow length $(9.00 \mathrm{~mm})$;

Inlet air temperature $\left(T_{\text {in }}\right)\left(20^{\circ} \mathrm{C}\right)$; 

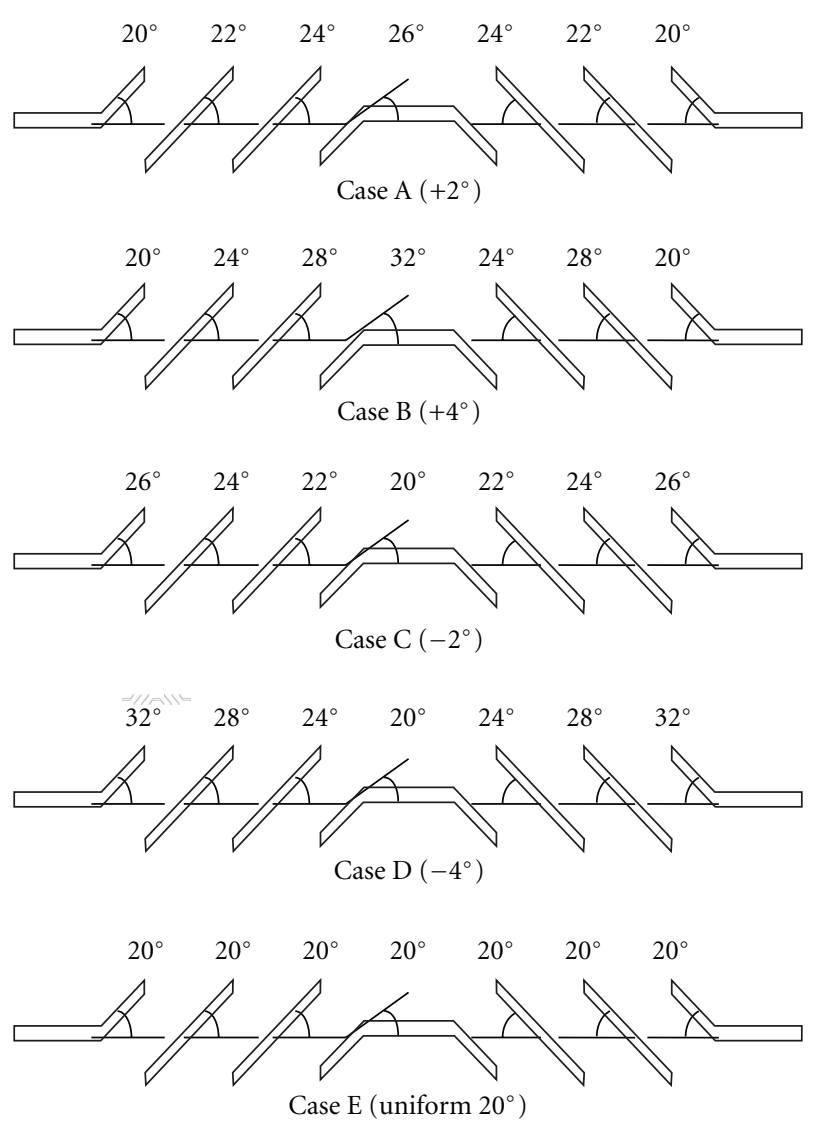

Figure 2: Five different cases of successively increased and decreased louver angle $\left(+2^{\circ},+4^{\circ},-2^{\circ},-4^{\circ}\right.$, and uniform angle $\left.20^{\circ}\right)$.

Inlet air pressure $\left(P_{\text {in }}\right)(0.0 \mathrm{~Pa})$;

Fin wall temperature $\left(T_{w}\right)\left(60^{\circ} \mathrm{C}\right)$;

Frontal velocity $\left(u_{\text {in }}\right)(0.3 \sim 15 \mathrm{~m} / \mathrm{s})$;

Louver angle (uniform angle of $20^{\circ}$ ).

2.4. Governing Equations. To focus on the effect of geometrical parameters with different arrangements of louver angle and variable fin pitch on the louvered fin CHE performance, the following assumptions are made: (i) both fluid flow and heat transfer are in steady state and three-dimensional; (ii) fluid is assumed to be incompressible and laminar; (iii) properties of both fluid and fin material are temperatureindependent; and (iv) At the solid surfaces of louver fins, noslip conditions and constant wall temperature $T_{w}\left(60^{\circ} \mathrm{C}\right)$ are specified which act as the heat generator and the temperature of it will be maintained throughout the simulation, so that it will supply heat to the region covered inside the domain. The continuity, momentum, and energy equations for the problem can be written as [18] the following.

\subsubsection{Continuity. Consider}

$$
\frac{\partial U}{\partial X}+\frac{\partial V}{\partial Y}+\frac{\partial W}{\partial Z}=0
$$

\subsubsection{Momentum}

X-Momentum. Consider

$$
\begin{aligned}
& \left(U \frac{\partial U}{\partial X}+V \frac{\partial U}{\partial Y}+W \frac{\partial U}{\partial Z}\right) \\
& \quad=-\frac{d P}{d X}+\frac{1}{\operatorname{Re}}\left(\frac{\partial^{2} U}{\partial X^{2}}+\frac{\partial^{2} U}{\partial Y^{2}}+\frac{\partial^{2} U}{\partial Z^{2}}\right) .
\end{aligned}
$$

Y-Momentum. Consider

$$
\begin{aligned}
\left(U \frac{\partial V}{\partial X}\right. & \left.+V \frac{\partial V}{\partial Y}+W \frac{\partial V}{\partial Z}\right) \\
& =-\frac{d P}{d Y}+\frac{1}{\operatorname{Re}}\left(\frac{\partial^{2} V}{\partial X^{2}}+\frac{\partial^{2} V}{\partial Y^{2}}+\frac{\partial^{2} V}{\partial Z^{2}}\right) .
\end{aligned}
$$

Z-Momentum. Consider

$$
\begin{aligned}
\left(U \frac{\partial W}{\partial X}\right. & \left.+V \frac{\partial W}{\partial Y}+W \frac{\partial W}{\partial Z}\right) \\
& =-\frac{d P}{d Z}+\frac{1}{\operatorname{Re}}\left(\frac{\partial^{2} W}{\partial X^{2}}+\frac{\partial^{2} W}{\partial Y^{2}}+\frac{\partial^{2} W}{\partial Z^{2}}\right) .
\end{aligned}
$$

\subsubsection{Energy. Consider}

$$
\begin{aligned}
& \left(U \frac{\partial \theta}{\partial X}+V \frac{\partial \theta}{\partial Y}+W \frac{\partial \theta}{\partial Z}\right) \\
& \quad=\frac{1}{\operatorname{Re} \cdot \operatorname{Pr}}\left(\frac{\partial^{2} \theta}{\partial X^{2}}+\frac{\partial^{2} \theta}{\partial Y^{2}}+\frac{\partial^{2} \theta}{\partial Z^{2}}\right),
\end{aligned}
$$

where $\mathrm{X}=x / F_{p}, Y=y / F_{p}, Z=z / F_{p}, U=u / u_{\text {in }}, V=u /$ $u_{\text {in }}$, and $W=w / u_{\text {in }}$. Pr is the Prandtl number, which is set equal to 0.71 (for air) in the present study.

2.5. Boundary Conditions. Boundary conditions for all the boundaries are specified for this simplified computational domain for all the cases studied. At the entrance of the domain $(X=0$, from Figure 1$)$, the inlet air temperature is taken as $20^{\circ} \mathrm{C}$ and the uniform inlet velocity of the air is calculated using Incropera and DeWitt [19].

$$
u_{\text {in }}=\frac{\operatorname{Re} \mu}{\rho F_{p}}, \quad U=\frac{u}{u_{\text {in }}},
$$

where $F_{p}$ is the fin pitch of the louvered fin and $u$ is the fluctuation velocity. In current simulations, following Park and Pak [20], the inlet velocity determines the Reynolds number of the flow. The Reynolds number considered in this work is ranged from 100 to 1000 . In calculating the inlet velocity of the air, the air is assumed to be evenly distributed through the louvered fins. The transverse velocities at the inlet are assumed to be zero. At the domain wall, not slip conditions are applied and the velocities are zero, and it is assumed to be an adiabatic surface.

Boundary conditions at the inlet:

$$
U=1, \quad \theta=1 .
$$

At the outlet:

$$
P=P_{\text {out }}, \quad \frac{\partial \theta}{\partial n}=0 .
$$


At the fluid-solid interface:

$$
\vec{U}=0, \quad \theta=\theta_{s}, \quad-\kappa_{s} \frac{\partial \theta_{s}}{\partial n}=-\kappa \frac{\partial \theta}{\partial n} .
$$

At the wall of fin:

$$
\theta_{w}=1
$$

In $(5 a),(5 b),(5 c)$, and $(5 d), U$ and $\theta$ are the dimensionless air inlet velocity and dimensionless temperature, respectively, $P$ is the dimensionless pressure at the outlet, $n$ is the direction normal to the wall or the outlet plane, and $\theta_{w}$ is the constant wall temperature. The constant wall temperature of $60^{\circ} \mathrm{C}$ is applied at all the fin surfaces in the domain. The thermophysical properties of air and solid used in the computation are $=1.225 \mathrm{~kg} / \mathrm{m}^{3}, \mathrm{c}_{\mathrm{p}}=1.005 \mathrm{~kJ} / \mathrm{kg} \cdot \mathrm{K}$, $\mu=0.00001 .7894 \mathrm{kgm} . \mathrm{s}, \kappa=0.0257 \mathrm{~W} / \mathrm{m} \cdot \mathrm{K}$, and $\kappa_{s}=$ $202.4 \mathrm{~W} / \mathrm{m} \cdot \mathrm{K}$.

\section{Numerical Solution Using FVM, Grid Testing, and Code Validation Numerical Procedure}

The governing conservations (1)-(3) with the corresponding boundary conditions and equations for solid and fluid phases are simultaneously solved as a single-domain conjugate problem using the finite-volume method (FVM) with a hybrid differencing scheme [18]. The standard SIMPLE algorithm is used as the computational algorithm [21, 22]. The iterations are continued until the sum of residuals for all computational cells became negligible (less than 10-7), and velocity components did not change from iteration to iteration. Because of the assumption of constant fluid properties and negligible buoyancy, the mass and momentum equations are not coupled to the energy equation. Therefore, the temperature field is calculated by solving the energy equation after a converged solution for the flow field is obtained by solving the momentum and continuity equations. A threedimensional mesh is generated for the numerical simulations, and an extensive mesh testing is performed to guarantee grid independent solutions. For this purpose, three grid systems, $112 \times 21 \times 10,212 \times 42 \times 10$, and $312 \times 42 \times 10$, are tested for inlet velocity, $u_{\text {in }}=5 \mathrm{~m} / \mathrm{s}$ to ensure the accuracy and validity of the numerical results. The results have shown that the relative errors in the local temperature and pressure between the solutions of $212 \times$ $42 \times 10$, and $312 \times 42 \times 10$ are less than $3.3 \%$. Thus, a computational cell with $212 \times 42 \times 10$ grids is employed throughout the computation for all analysis in this study. To validate the present computational model, the comparison of present results with data available from Hsieh and Jang [10] is presented in Figure 3, which shows the variation of Nusselt number along the flow direction. The Nusselt number obtained from present study has been computed using increased louver angle by $4^{\circ}$ (case B) with inlet velocity of $5 \mathrm{~m} / \mathrm{s}$. As shown in Figure 3, the comparison between the present results and data of Hsieh and Jang [10] is agreed well. It can be also observed that, for both present and Hsieh and Jang [10] study, the variation of Nusselt number is in the form of fluctuating by having a maximum and a minimum value for each louver along the flow direction.

\section{Results and Discussion}

The performance of $\mathrm{CHE}$ with louvered fins on thermal and hydraulic analysis is affected by the geometry of its components. The present study mainly evaluates the effect of louver angle and fin pitch on the flow and heat transfer. To study the effect of louver angle, five different cases of different arrangement of louver angles are carried out which are case $\mathrm{A}\left(+2^{\circ}\right)$, case $\mathrm{B}\left(+4^{\circ}\right)$, case $\mathrm{C}\left(-2^{\circ}\right)$, case $\mathrm{D}\left(-4^{\circ}\right)$, and case $\mathrm{E}$ (uniform $=20^{\circ}$ ). For the effect of fin pitch, the analysis is carried out with fixed louver angle at $20^{\circ}$ throughout along the fin but the fin pitch is now chosen to be the variables which are case A $(4 \mathrm{~mm})$, case B $(2 \mathrm{~mm})$, and case $C(1 \mathrm{~mm})$.

4.1. Effect of Variable Louver Angle with Fixed Fin Pitch. Figures 4 and 5 illustrate the Nusselt number $(\mathrm{Nu})$ and pressure drop coefficient $\left(C_{p}\right)$, respectively, along the flow direction with inlet frontal velocity $u_{\text {in }}=5.0 \mathrm{~m} / \mathrm{s}(\operatorname{Re}=500)$ for all the cases. The local heat transfer coefficient can be expressed in the dimensionless form by the Nusselt number $\mathrm{Nu}$ defined as

$$
\mathrm{Nu}=\frac{h F_{p}}{k}
$$

where $h$ is defined as

$$
h=\frac{q^{\prime \prime}}{T_{w}-T_{b}},
$$

where $q^{\prime \prime}$ is the local heat flux, $T_{w}$ is the constant wall temperature $\left(60^{\circ} \mathrm{C}\right)$, and $T_{b}$ is the local bulk mean temperature of the fluid.

It can be seen from Figure 4 that the there is a maximum and minimum value of $\mathrm{Nu}$ of each louver for all the cases due to the repeated growth and destruction of the boundary layer [10]. It is also found that $\mathrm{Nu}$ for each case (cases $\mathrm{A}-\mathrm{D}$ ) is higher than those for the uniform louver angle (case E). The highest $\mathrm{Nu}$ is obtained for case $\mathrm{B}$, followed by case $\mathrm{D}$, $\mathrm{A}$, and C. This is because the larger louver acts to interrupt the airflow and creates a series of thin boundary layers that have lower thermal resistance as reported by Hashim [23]. This results in higher heat transfer performance for larger louvered angle fins of CHE. However, a larger louver angle would also contribute to the increase in the pressure drop coefficient as seen from Figure 5. The local pressure drop can be expressed in terms of the dimensionless pressure coefficient $C_{p}$ defined as

$$
C_{p}=\frac{P_{\text {in }}-P}{(1 / 2) \rho u_{\text {in }}^{2}},
$$

where $P_{\text {in }}$ is the pressure at inlet.

It is shown that $C_{p}$ for all the cases (cases A-D) is higher than those for the uniform louver angle (case $\mathrm{E}$ ), and changes in $C_{p}$ is more significant especially at the flow exitance.

4.2. Effect of Louver Fin with Variable Fin Pitch. For all cases of louvered fins of CHE studied, it is observed that the higher temperature region occurs near the louvers at flow 


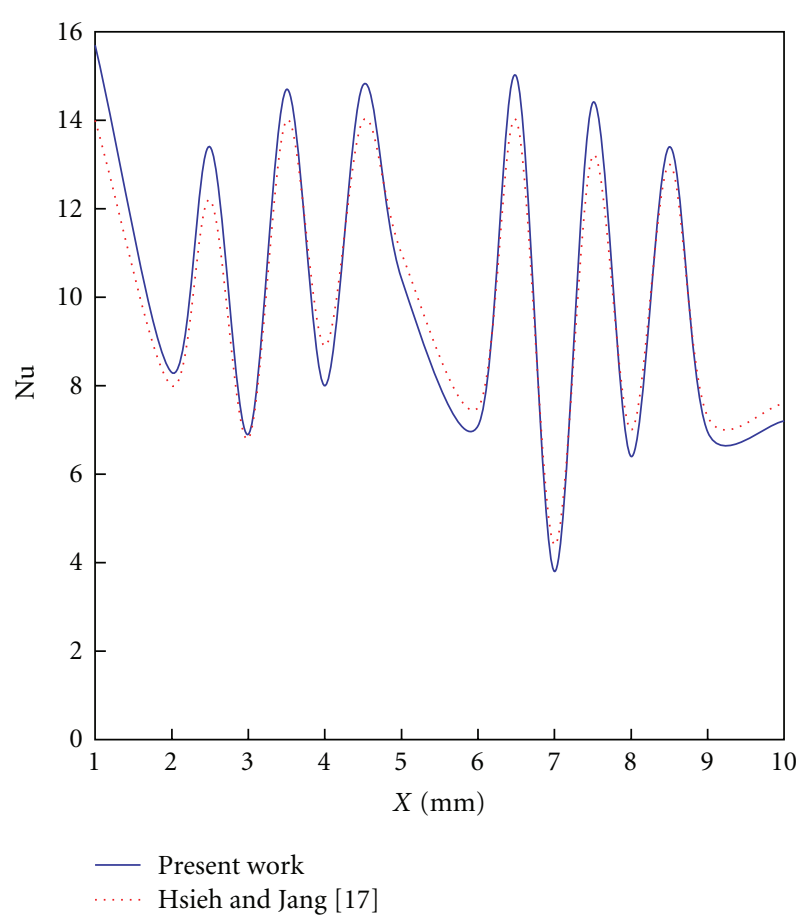

Figure 3: Comparison of the present numerical results with the numerical results from Hsieh and Jang [10] for nusselt number along the flow direction for case $\mathrm{B}\left(+4^{\circ}\right)$ with inlet velocity of $5 \mathrm{~m} / \mathrm{s}$.

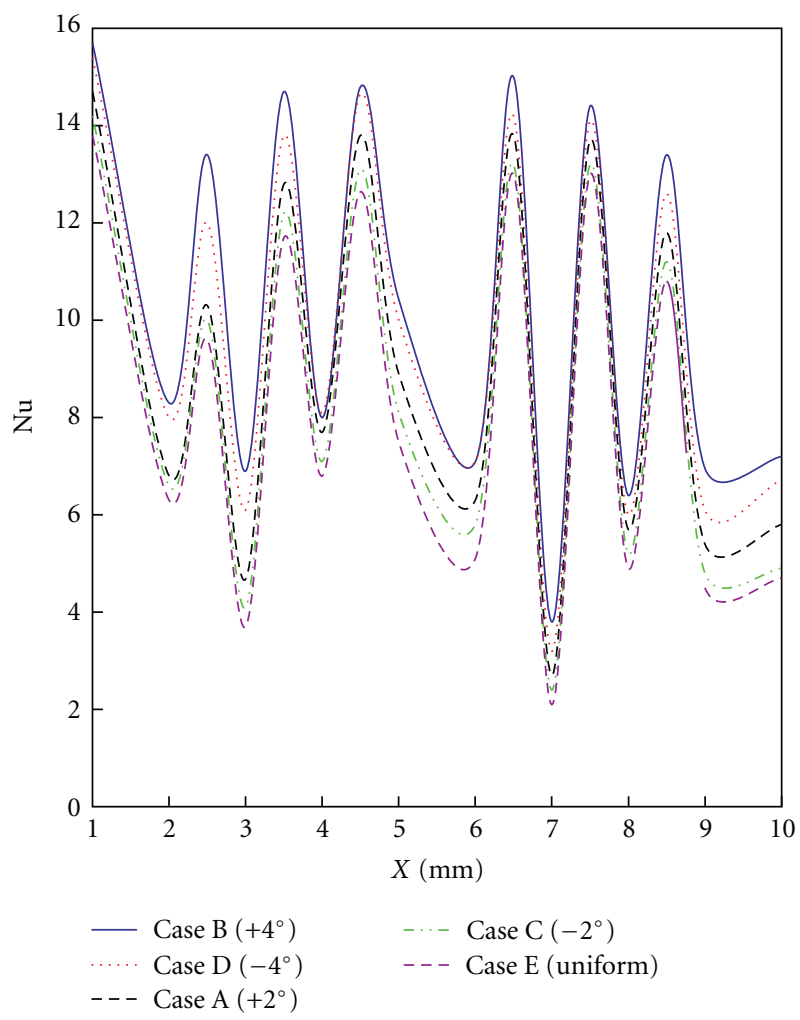

Figure 4: The variation of $\mathrm{Nu}$ along the flow direction for five different cases of successively increased and decreased louver angle with $\operatorname{Re}=500$.

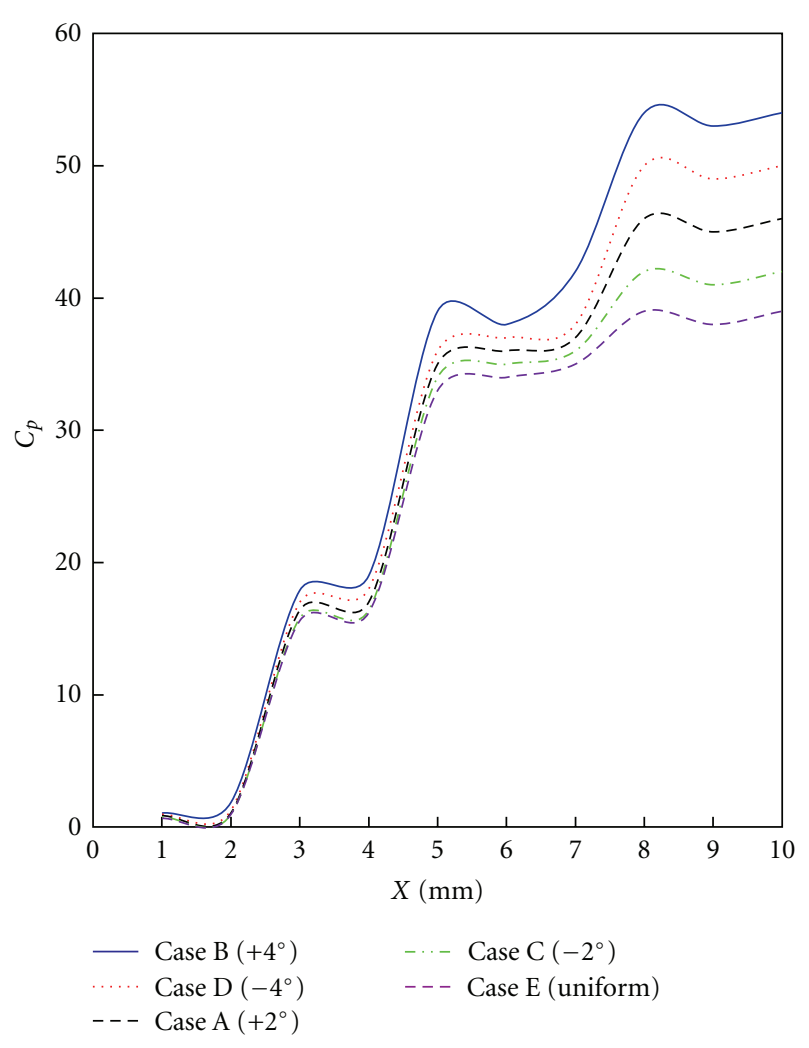

Figure 5: The variation of $C_{p}$ along the flow direction for five different cases of successively increased and decreased louver angle with $\operatorname{Re}=500$.

exitance while minimum temperature occurs in the region near the flow entrance zones. Figure 6 shows the temperature distribution of uniform louver angle $\left(20^{\circ}\right)$ with fin pitch of $1 \mathrm{~mm}$ (case A) at $\mathrm{Re}=500$ according to the phenomena described above. Although the temperature distribution for all the cases is not shown in the figure, but the similar trend is obtained as well as for case B and C. However, the temperature gradient is more pronounced for smaller fin pitch compared to the larger one. Therefore, higher heat transfer performance is expected for louvered fin with smaller pitch. Figure 7 shows the pressure distribution of the $\mathrm{CHE}$ for uniform louver angle $\left(20^{\circ}\right)$ with fin pitch of $4 \mathrm{~mm}$ (case A) with $\mathrm{Re}=500$. It is observed that the high pressure region occurs at the entrance, and low pressure region occurs at outlet of the CHE. It is also inferred from Figure 7 that the pressure is decreasing along the flow from inlet to outlet. A similar trend is observed for all the cases studied. It is found that the pressure gradient for case $\mathrm{A}$ is more apparent compared to case B and C. Thus, the higher pressure drop may occur in louvered fin with smaller pitch. It should be noted that the fluid path in the numerical simulation does not include the fittings and pipes between the pressure transducers used in the actual design of an CHE [23].

The effects of fin pitch on the thermal hydraulic performance are evaluated in terms of Nusselt number $(\mathrm{Nu})$ and pressure drop coefficient $\left(C_{p}\right)$. The $\mathrm{Nu}$ and $C_{p}$ for three different values of fin pitches (cases $\mathrm{A}-\mathrm{C}$ ) are calculated using 

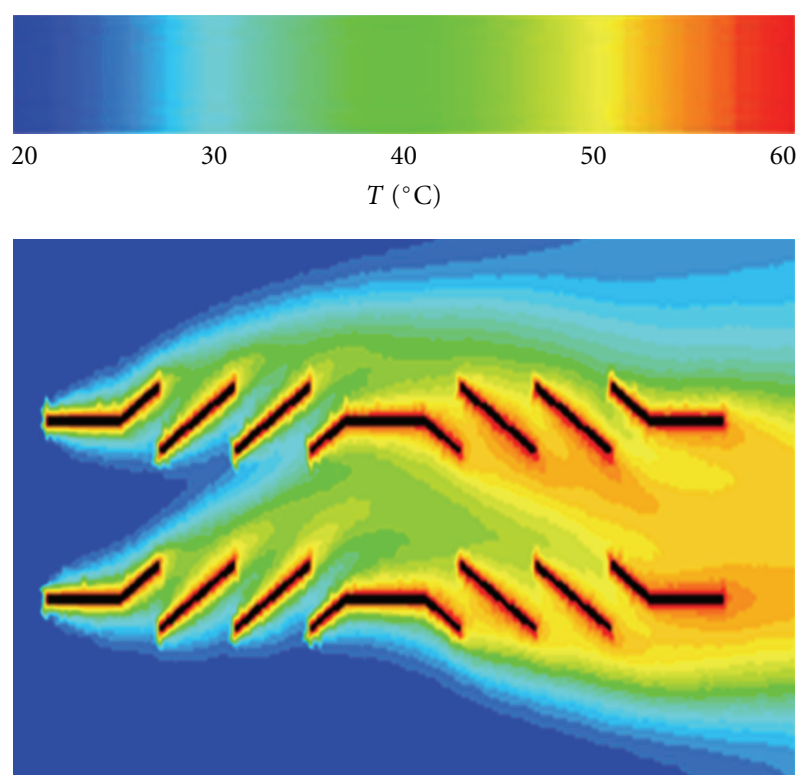

FIgure 6: Temperature distribution along the flow direction for uniform louver angle $\left(20^{\circ}\right)$ with fin pitch of $1 \mathrm{~mm}$ (case A) and $\mathrm{Re}=$ 500.
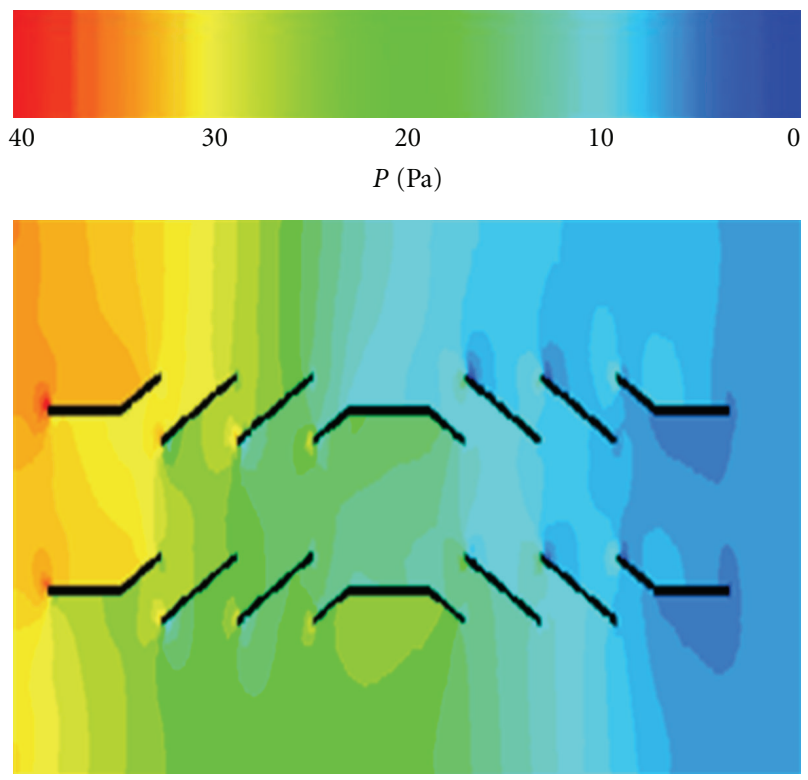

FIgURE 7: Pressure distribution along the flow direction for uniform louver angle $\left(20^{\circ}\right)$ with fin pitch of $1 \mathrm{~mm}$ (case A) and $\operatorname{Re}=500$.

(6) and (8) and presented in Figures 8 and 9, respectively. It can be seen from Figure 8 that the smallest fin pitch (case A) yields higher values of $\mathrm{Nu}$ compared to case $\mathrm{B}$ and $\mathrm{C}$. The reason why louvered fin with smaller pitch provides better heat transfer performance compared to the larger one is that the louver with smaller pitch caused the more disturbances in flow of the working fluid and the boundary layer relative to the elemental flat-plate surfaces [13] which has been proven in current results. Generally, the flow in louvered fin with smaller pitch generates more swirls and recirculation around their corners, thereby resulting in large pressure drop as reported by many researchers [24-28]. This engenders larger $C_{p}$ in case $\mathrm{A}$, followed by cases $\mathrm{B}$ and $\mathrm{C}$ as shown in Figure 9. Thus, the present results indicated the successively louvered fin with smaller pitch patterns applied in CHE could effectively enhance the heat transfer performance with the pressure drop penalty.

The averaged Nusselt number $(\mathrm{Nu})$ distribution with Reynolds number for different fin pitch values (cases A-C) is shown in Figure 10. It can be seen that as the Reynolds number increases, $\mathrm{Nu}$ for all the cases examined also increases nearly linearly. This is because the Reynolds number is increased by increasing the inlet velocity. As a result, there will be an increment of fluid velocity inside the flow through the fins. Therefore, this increment disturbs the flow, and the heat transfer is strengthened when the Reynolds number is increased. It can be observed from this figure that the $\mathrm{Nu}$ for case $\mathrm{A}$ is the highest followed by cases $\mathrm{B}$ and $\mathrm{C}$ at all numbers of Reynolds number. The difference in $\mathrm{Nu}$ between the cases $\mathrm{A}-\mathrm{C}$ is more apparent at higher Reynolds number. This is because, at higher Reynolds number, the boundary layers are thinner and the flow itself is almost aligned with the louvers which cause the difference among cases A-C to be more significant [23]. The pressure drop coefficient $\left(C_{p}\right)$ profile versus Reynolds number for different fin pitch value configurations is shown in Figure 11. From this figure, it can be seen that the $C_{p}$ rises almost linearly with the increase of Reynolds number. A similar trend is observed for all the cases studied.

\section{Conclusion}

Numerical simulations on fluid flow and heat transfer characteristics over louver angle fin CHEs are reported in this study. Flow is assumed to be laminar and three-dimensional, and a computational domain from the fluid inlet to outlet is solved directly for the Reynolds number ranged from 100 to 1000 . The impacts of using variable louver angles $\left(+2^{\circ}\right.$, $+4^{\circ},-2^{\circ},-4^{\circ}$, and uniform angle $\left.20^{\circ}\right)$ and louvered fin with variable fin pitches $(1 \mathrm{~mm}, 2 \mathrm{~mm}$, and $4 \mathrm{~mm}$ ) on both thermal and hydraulic of CHE are presented, investigated, and compared. Based on the obtained results, the following conclusions can be drawn.

(1) There is a maximum and minimum value of Nusselt number at each louver along the flow direction because of the repeated growth and destruction of the boundary layer. The Nusselt number are all higher for successively increased or decreased louver angle compared to uniform louver angle, and the highest value of Nusselt number is achieved for case B $\left(+4^{\circ}\right)$.

(2) The result revealed that the pressure drop coefficient for all the cases of successively increased or decreased louver angle (cases A-D) is higher than those for the uniform louver angle (case E), and the highest value of pressure drop coefficient is achieved for case B $\left(+4^{\circ}\right)$. Thus, larger louvered angle fin contributes to the greater pressure drop penalty. 


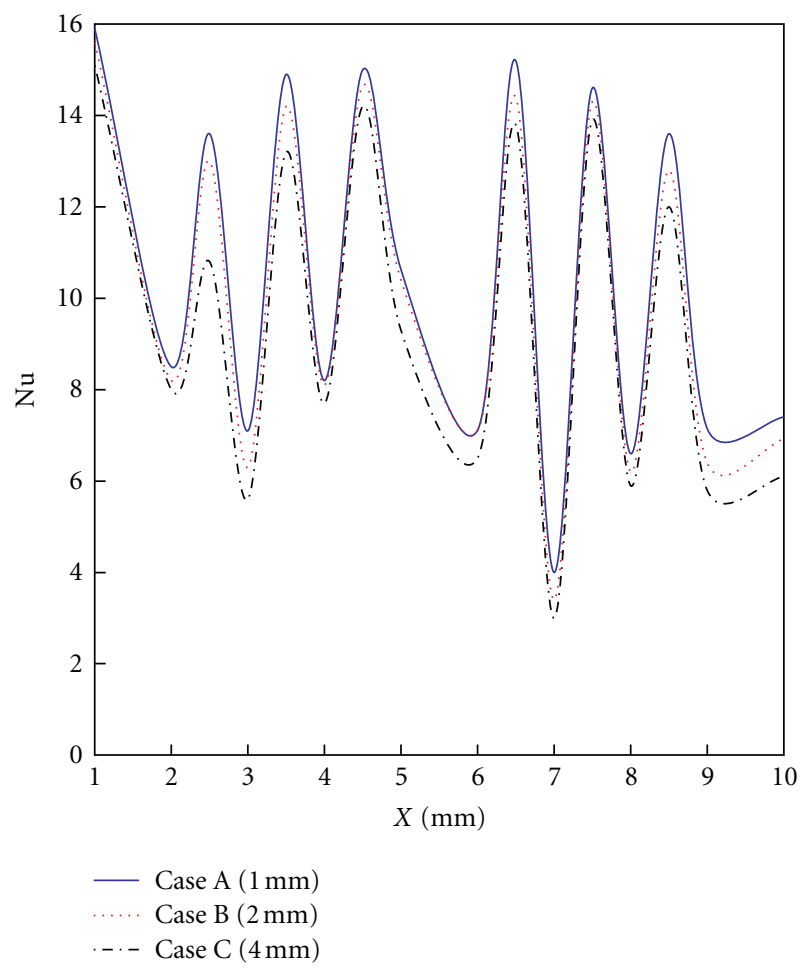

FIGURE 8: The variation of $\mathrm{Nu}$ along the flow direction for variable fin pitch with uniform louver angle of $20^{\circ}$ and $\mathrm{Re}=500$.

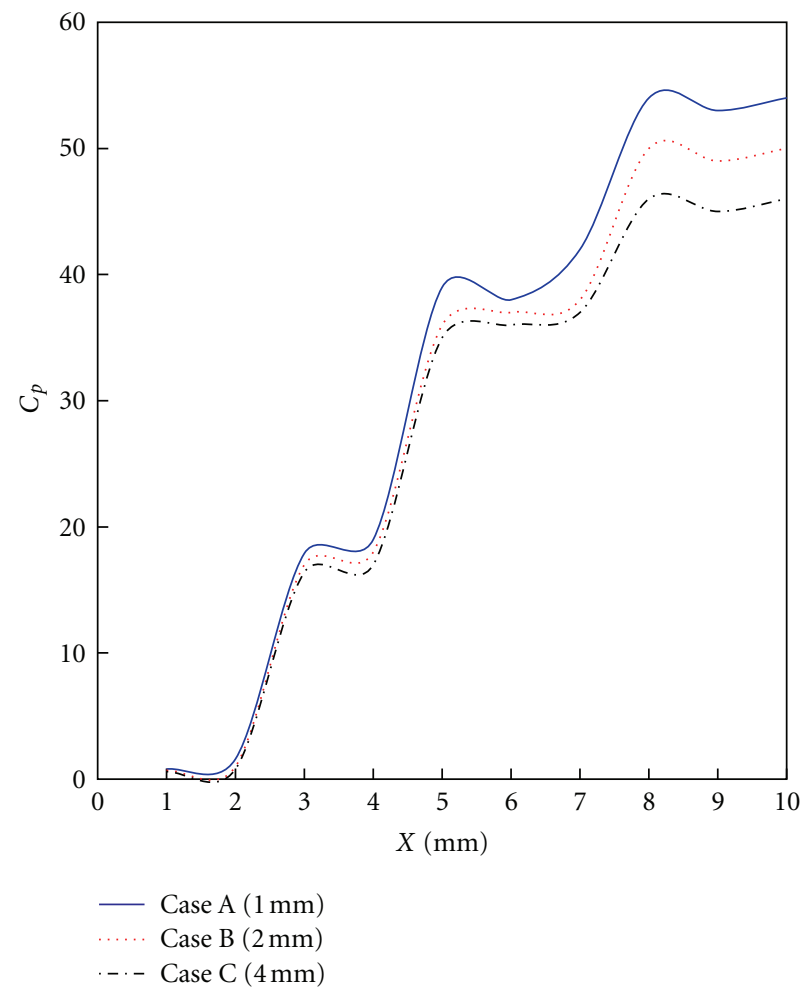

Figure 9: The variation of $C_{p}$ along the flow direction for variable fin pitch with uniform louver angle of $20^{\circ}$ and $\mathrm{Re}=500$.

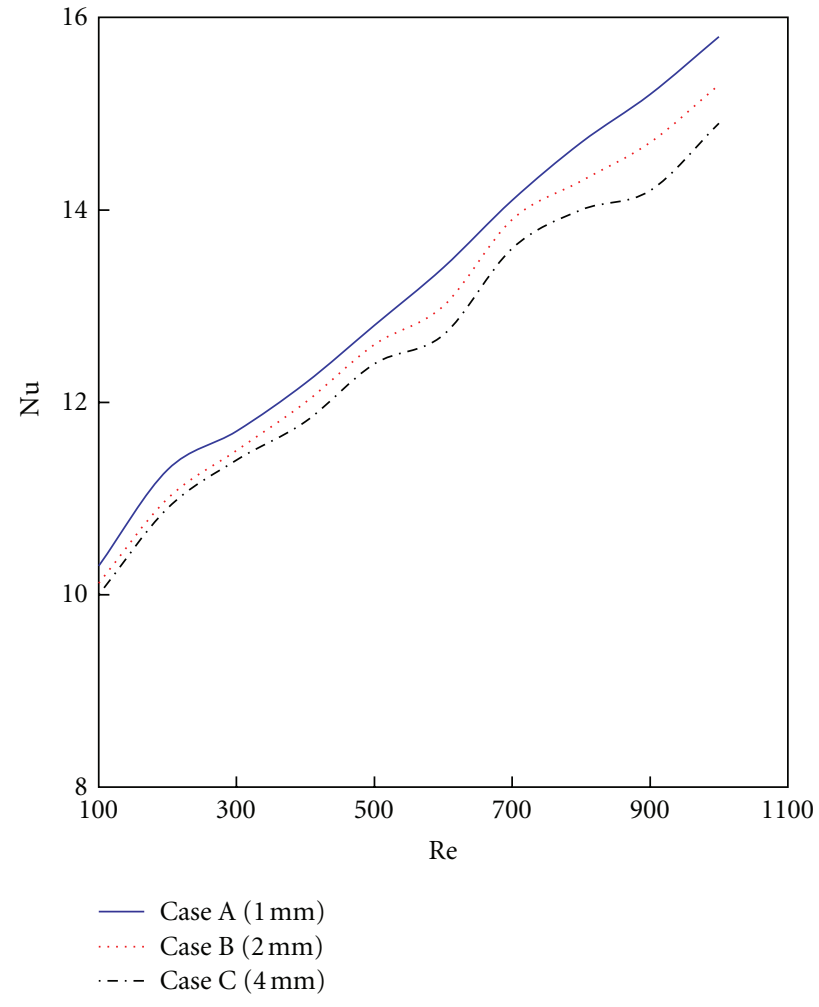

FIGURE 10: The variation of averaged, Nu versus Re for variable fin pitch with uniform louver angle of $20^{\circ}$.

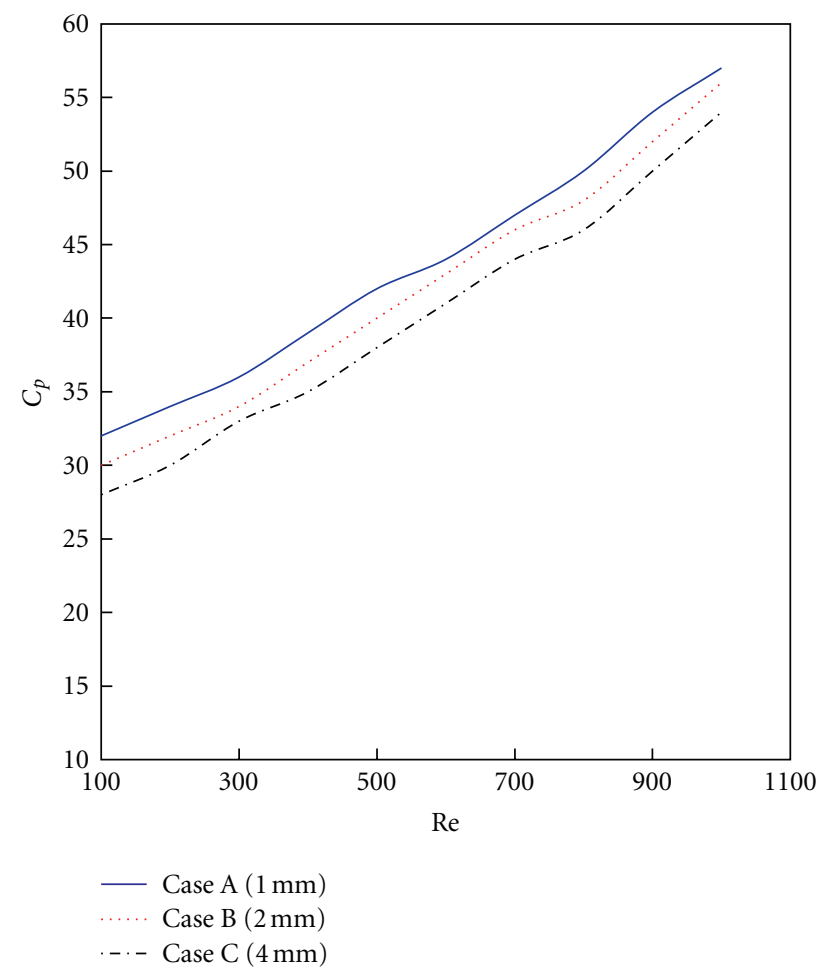

FIGURE 11: The variation of averaged, $C_{p}$ versus Re for variable fin pitch with uniform louver angle of $20^{\circ}$. 
(3) Both the Nusselt number and pressure drop coefficient increase with the decrease of fin pitch and increase of Reynolds number. The heat transfer enhancement for smallest fin pitch $(1 \mathrm{~mm})$ is more apparent at high Reynolds number.

(4) Thus, the successively variable louver angle patterns and louver fin with smaller pitch applied in CHEs could effectively enhance the heat transfer performance with moderate degradation of pressure drop penalty compared to plain fin surface of $\mathrm{CHE}$.

\section{Nomenclature}

$C_{p}: \quad$ Pressure drop coefficient

$\mathrm{c}_{\mathrm{p}}$ : $\quad$ Specific heat, $\mathrm{J} / \mathrm{kg} \cdot \mathrm{K}$

$F_{p}: \quad$ fin pitch, $\mathrm{mm}$

$L_{p}: \quad$ Louver pitch, $\mathrm{mm}$

L: $\quad$ Flow length, $\mathrm{mm}$

$h$ : $\quad$ Heat transfer coefficient, $\mathrm{W} / \mathrm{m}^{2} \cdot \mathrm{K}$

$k$ : $\quad$ Fluid thermal conductivity, $\mathrm{W} / \mathrm{m} \cdot \mathrm{K}$

$n$ : Direction normal to the wall

Nu: $\quad$ Nusselt number

$P_{\text {in }}: \quad$ Inlet pressure, $\mathrm{Pa}$

$P_{\text {out}}: \quad$ Outlet pressure, $\mathrm{Pa}$

Pr: $\quad$ Prandtl number

Re: Reynolds number

T: $\quad$ Temperature, $\mathrm{K}$

$T_{\text {in }}$ : Fluid inlet temperature, $\mathrm{K}$

$T_{\mathrm{s}}$ : $\quad$ Surface temperature, $\mathrm{K}$

$u$ : Fluid velocity, $\mathrm{m} / \mathrm{s}$

$u_{\text {in }}$ : Frontal inlet fluid velocity, $\mathrm{m} / \mathrm{s}$

$X, Y, Z: 3 \mathrm{D}$ cartesian coordinates

$X: \quad$ Axial distance from the inlet, $\mathrm{m}$.

\section{Greek Symbols}

$\ell$ : Fin thickness, mm

$\mu$ : Dynamic viscosity, Ns $/ \mathrm{m}^{2}$

$\rho$ : Density, kg/m.

\section{Subscripts \\ $i$ : inlet \\ $o$ : outlet \\ $s:$ solid \\ $w$ : wall.}

\section{Acknowledgment}

The authors would like to sincerely thank the Ministry of Higher Education (MOHE) of Malaysia for the provision of a Grant with code No. 12012011ERGS to support this work.

\section{References}

[1] R. L. Webb, Principals of Enhanced Heat Transfer, John Wiley \& Sons, New York, NY, USA, 1994.

[2] P. Gunnasegaran, N. H. Shuaib, M. F. AbdulJalal, and E. Sandhita, "Numerical study of fluid dynamic and heat transfer in a compact heat exchanger using nanofluids," ISRN Mechanical Engineering, vol. 2012, Article ID 585496, 11 pages, 2012.

[3] K. Y. Leong, R. Saidur, S. N. Kazi, and A. H. Mamun, "Performance investigation of an automotive car radiator operated with nanofluid-based coolants (nanofluid as a coolant in a radiator)," Applied Thermal Engineering, vol. 30, no. 17-18, pp. 2685-2692, 2010.

[4] T. Kuppan, Heat Exchanger Design Handbook, Marcel Dekker, New York, NY, USA, 2000.

[5] E. A. M. Elshafei, M. M. Awad, E. El-Negiry, and A. G. Ali, "Heat transfer and pressure drop in corrugated channels," Energy, vol. 35, no. 1, pp. 101-110, 2010.

[6] R. L. Webb, Principles of Enhanced Heat Transfer, John Wiley and Sons, New York, NY, USA, 1994.

[7] R. L. Webb and P. Trauger, "How structure in the louvered fin heat exchanger geometry," Experimental Thermal and Fluid Science, vol. 4, no. 2, pp. 205-217, 1991.

[8] A. Sahnoun and R. L. Webb, "Prediction of heat transfer and friction for the louver fin geometry," Journal of Heat Transfer, vol. 114, no. 4, pp. 893-900, 1992.

[9] M. H. Kim and C. W. Bullard, "Air-side thermal hydraulic performance of multi-louvered fin aluminum heat exchangers," International Journal of Refrigeration, vol. 25, no. 3, pp. 390400, 2002.

[10] C. T. Hsieh and J. Y. Jang, "3-D thermal-hydraulic analysis for louver fin heat exchangers with variable louver angle," Applied Thermal Engineering, vol. 26, no. 14-15, pp. 1629-1639, 2006.

[11] T. L. Phan, K. S. Chang, Y. C. Kwon, and J. T. Kwon, "Experimental study on heat and mass transfer characteristics of louvered fin-tube heat exchangers under wet condition," International Communications in Heat and Mass Transfer, vol. 38, no. 7, pp. 893-899, 2011.

[12] Y. Zhong and A. M. Jacobi, "An experimental study of louverfin flat-tube heat exchanger performance under frosting conditions," in Proceedings of the 5th International Conference on Enhanced, Compact and Ultra-Compact Heat Exchangers: Science, Engineering and Technology, Engineering Conferences International, Hoboken, NJ, USA, September 2005.

[13] T. A. Cowell, M. R. Heikal, and A. Achaichia, "Flow and heat transfer in compact louvered fin surfaces," Experimental Thermal and Fluid Science, vol. 10, no. 2, pp. 192-199, 1995.

[14] A. Achaichia and T. A. Cowell, "Heat transfer and pressure drop characteristics of flat tube and louvered plate fin surfaces," Experimental Thermal and Fluid Science, vol. 1, no. 2, pp. 147-157, 1988.

[15] V. P. Malapure, S. K. Mitra, and A. Bhattacharya, "Numerical investigation of fluid flow and heat transfer over louvered fins in compact heat exchanger," International Journal of Thermal Sciences, vol. 46, no. 2, pp. 199-211, 2007.

[16] D. Jung and D. N. Assanis, "Numerical modeling of cross flow compact heat exchanger with louvered fins using thermal resistance concept," SAE Paper 2006-01-0726, 2006.

[17] M. Kajino and M. Hiramatsu, "Research and development of automotive heat exchangers," in Heat Transfer in High Technology and Power Engineering, W. J. Wang and Y. Mori, Eds., pp. 420-432, Hemisphere, Washington, DC, USA, 1987.

[18] S. V. Patankar, Numerical Heat Transfer and Fluid Flow, Hemisphere, New York, NY, USA, 1980.

[19] F. P. Incropera and D. P. DeWitt, Introduction to Heat Transfer, John Wiley \& Sons, New York, NY, USA, 3rd edition, 1996.

[20] K. W. Park and H. Y. Pak, "Flow and heat transfer characteristics in flat tubes of a radiator," Numerical Heat Transfer A, vol. 41, no. 1, pp. 19-40, 2002. 
[21] H. K. Versteeg and W. Malalasekera, An Introduction to Computational Fluid Dynamics: The Finite Volume Method, John Wiley and Sons, New York, NY, USA, 1995.

[22] J. D. Anderson, Computational Fluid Dynamic: The Basics with Applications, McGraw-Hill, New York, NY, USA, 1995.

[23] M. F. Hashim, Modeling Compact Heat Exchanger Surface, Faculty of Mechanical Eng. Kolej Universiti Teknikal Kebangsaan Malaysia, 2005.

[24] T. L. Ngo, Y. Kato, K. Nikitin, and T. Ishizuka, "Heat transfer and pressure drop correlations of microchannel heat exchangers with S-shaped and zigzag fins for carbon dioxide cycles," Experimental Thermal and Fluid Science, vol. 32, no. 2, pp. 560-570, 2007.

[25] H. A. Mohammed, P. Gunnasegaran, and N. H. Shuaib, "Numerical simulation of heat transfer enhancement in wavy microchannel heat sink," International Communications in Heat and Mass Transfer, vol. 38, no. 1, pp. 63-68, 2011.

[26] H. A. Mohammed, P. Gunnasegaran, and N. H. Shuaib, "Influence of channel shape on the thermal and hydraulic performance of microchannel heat sink," International Communications in Heat and Mass Transfer, vol. 38, no. 4, pp. 474-480, 2011.

[27] R. Chein and J. Chen, "Numerical study of the inlet/outlet arrangement effect on microchannel heat sink performance," International Journal of Thermal Sciences, vol. 48, no. 8, pp. 1627-1638, 2009.

[28] S. Kandlikar, S. Garimella, D. Li, S. Colin, and M. R. King, Heat Transfer and Fluid Flow in Minichannels and Microchannels, Elsevier, Maryland Heights, Mo, USA, 2005. 

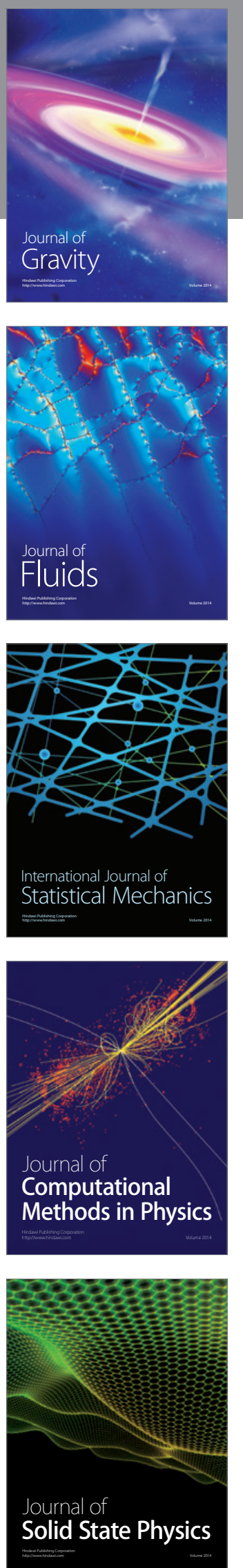
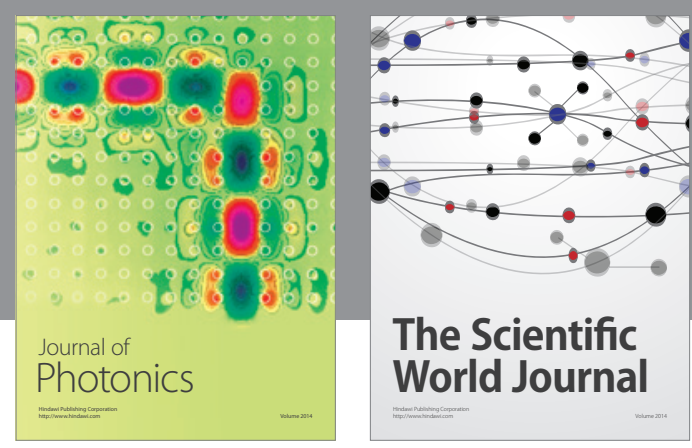

The Scientific World Journal

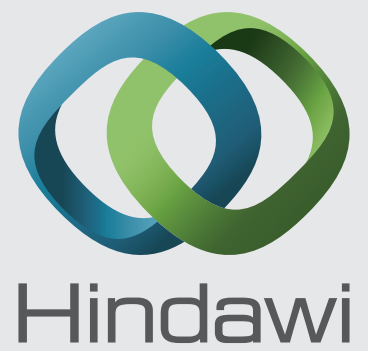

Submit your manuscripts at http://www.hindawi.com
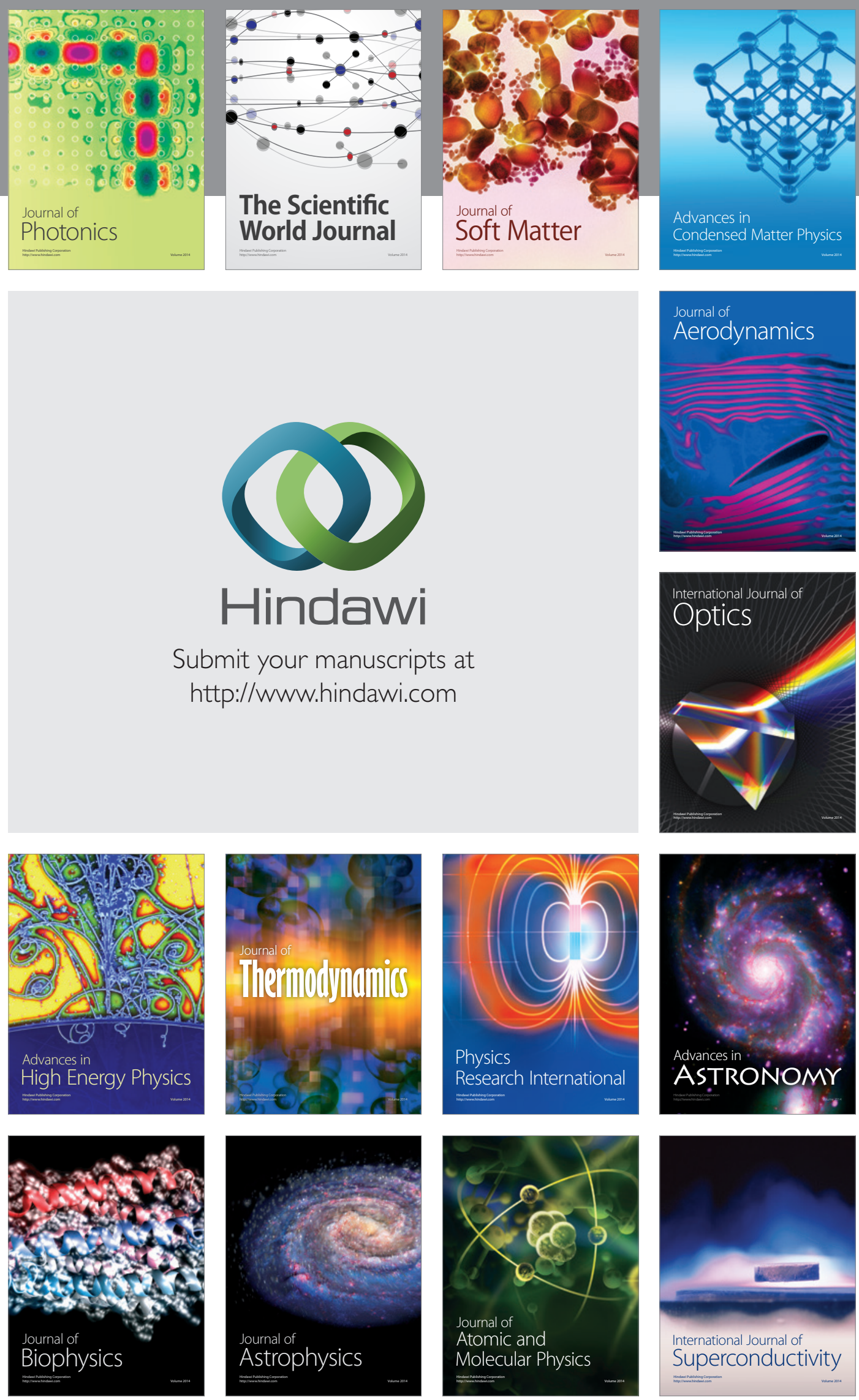
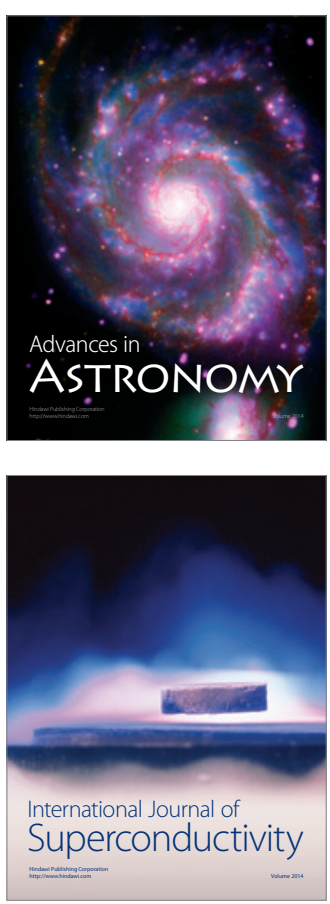